\title{
The Effectiveness of Web-Based Interventions Delivered to Children and Young People With Neurodevelopmental Disorders: Systematic Review and Meta-Analysis
}

Kareem Khan ${ }^{1}$, BSc, MSc; Charlotte L Hall ${ }^{1}$, BSc, MSc, PhD; E Bethan Davies ${ }^{1,2}$, BSc, MSc, PhD; Chris Hollis ${ }^{1,2,3}$, MBBS, BSc, DCH, PhD, FRCPsych; Cris Glazebrook ${ }^{1,2}$, RGN, PhD, CPsychol

\footnotetext{
${ }^{1}$ Division of Psychiatry and Applied Psychology, Institute of Mental Health, University of Nottingham, Nottingham, United Kingdom

${ }^{2}$ NIHR MindTech Medtech Co-operative, Institute of Mental Health, University of Nottingham, Nottingham, United Kingdom

${ }^{3}$ NIHR Nottingham Biomedical Research Centre, Nottingham, United Kingdom
}

\section{Corresponding Author:}

Kareem Khan, BSc, MSc

Division of Psychiatry and Applied Psychology

Institute of Mental Health

University of Nottingham

Innovation Park, Triumph Road

Nottingham, NG7 2TU

United Kingdom

Phone: 4401158232438

Email: kareem.khan@nottingham.ac.uk

\section{Abstract}

Background: The prevalence of certain neurodevelopmental disorders, specifically autism spectrum disorder (ASD) and attention deficit hyperactivity disorder (ADHD), has been increasing over the last four decades. Nonpharmacological interventions are available that can improve outcomes and reduce associated symptoms such as anxiety, but these are often difficult to access. Children and young people are using the internet and digital technology at higher rates than any other demographic, but although Web-based interventions have the potential to improve health outcomes in those with long-term conditions, no previous reviews have investigated the effectiveness of Web-based interventions delivered to children and young people with neurodevelopmental disorders.

Objective: This study aimed to review the effectiveness of randomized controlled trials (RCTs) of Web-based interventions delivered to children and young people with neurodevelopmental disorders.

Methods: Six databases and one trial register were searched in August and September 2018. RCTs were included if they were published in a peer-reviewed journal. Interventions were included if they (1) aimed to improve the diagnostic symptomology of the targeted neurodevelopmental disorder or associated psychological symptoms as measured by a valid and reliable outcome measure; (2) were delivered on the Web; (3) targeted a youth population (aged $\leq 18$ years or reported a mean age of $\leq 18$ years) with a diagnosis or suspected diagnosis of a neurodevelopmental disorder. Methodological quality was rated using the Joanna Briggs Institute Critical Appraisal Checklist for RCTs.

Results: Of 5140 studies retrieved, 10 fulfilled the inclusion criteria. Half of the interventions were delivered to children and young people with ASDs with the other five targeting ADHD, tic disorder, dyscalculia, and specific learning disorder. In total, 6 of the 10 trials found that a Web-based intervention was effective in improving condition-specific outcomes or reducing comorbid psychological symptoms in children and young people. The 4 trials that failed to find an effect were all delivered by apps. The meta-analysis was conducted on five of the trials and did not show a significant effect, with a high level of heterogeneity detected $\left(\mathrm{n}=182[33.4 \%, 182 / 545], 5 \mathrm{RCTs}\right.$; pooled standardized mean difference $=-0.39 ; 95 \% \mathrm{CI}-0.98$ to $0.20 ; \mathrm{Z}=-1.29 ; P=.19\left[\mathrm{I}^{2}=72 \%\right.$; $P=.006])$.

Conclusions: Web-based interventions can be effective in reducing symptoms in children and young people with neurodevelopmental disorders; however, caution should be taken when interpreting these findings owing to methodological limitations, the minimal number of papers retrieved, and small samples of included studies. Overall, the number of studies was small and mainly limited to ASD, thus restricting the generalizability of the findings. 
Trial Registration: PROSPERO International Prospective Register of Systematic Reviews: CRD42018108824; http://www.crd.york.ac.uk/PROSPERO/display_record.php?ID=CRD42018108824

(J Med Internet Res 2019;21(11):e13478) doi: 10.2196/13478

\section{KEYWORDS}

online intervention; effectiveness; neurodevelopmental disorders; children and young people; methodology; systematic review

\section{Introduction}

\section{Background}

Web-based interventions for children and young people (CYP) with physical and psychological problems are relatively new phenomena, with the first trials of internet-delivered therapies being conducted in the late 1990s [1]. However, they are very important developments in the access to health care and treatment for CYP with long-term chronic health conditions. Neurodevelopmental disorders (NDDs) are a group of disorders that typically manifest early in development and are characterized by deficits in cognitive function, motor function, verbal communication, social skills, and behaviors [2]. Common NDDs include autism spectrum disorder (ASD), attention deficit hyperactivity disorder (ADHD), specific learning disorder (including dyscalculia and dyslexia), intellectual disability (ID), and tic disorder ([TD], including tourette syndrome and chronic tic disorder [CTD]) [3]. NDDs frequently co-occur, for example, individuals with ASD often have ID, and many children with ADHD have a specific learning disorder [3]. CYP with NDDs also have complex comorbidities and related symptoms, such as depression and anxiety [4]. There is growing evidence that the impact of NDD is lifelong for many individuals [5], and although exact prevalence rates of NDDs vary considerably between countries, researchers suggest that the prevalence of certain NDDs, specifically ASD and ADHD, has been increasing over the last four decades [6-8].

Psychological therapeutic interventions exist for a range of NDDs. These include therapies to manage NDD symptoms, such as habit reversal therapy for TDs, behavioral therapy to alleviate commonly associated symptoms, such as cognitive behavioral therapy (CBT) for anxiety symptoms, and psychoeducation to facilitate the management of NDDs. Owing to their complexity and chronic nature, pharmacotherapy may often be used as part of a treatment plan [9]. However, pharmacological interventions are considered undesirable for children because of the associated side effects [10]; therefore, psychological treatment is more desirable. A major barrier to psychological treatment is difficulty in accessing appropriately trained therapists, because of the limited numbers of therapists in child mental health services relative to the demand and the uneven geographical distribution of services. It is likely that Web-based therapy can help increase the availability and uptake of evidence-based interventions, offering the opportunity to deliver less therapist-intensive but effective interventions over long distances. Given that Web-based technology is a ubiquitous part of everyday life and young people are by far the highest users [11], Web-delivered therapy is intuitively attractive for CYP.
Web-based interventions are self-guided or therapist-assisted programs with the aim of improving knowledge, providing support, care, or treatment to a diverse population with a range of health problems. In the field of psychological and neurodevelopmental health, Web-based therapeutic interventions have been designed for CYP with a range of problems including ADHD [12], anxiety [13], depression [14], and obsessive-compulsive disorder [15]. These interventions all differ in the type of therapy delivered, their level of participant interaction with the program, number of sessions (dosage), level of trained expert support, structure, modality, and whether there is a parent component or not. However, little is known about what characteristics are integral to efficacious Web-based interventions, especially for CYP. There is some literature in adult populations to suggest that guided Web-based interventions are more efficacious than self-guided or unguided interventions [16], and the most effective interventions tend to be individualized to the user and more intensive [17]. To improve the future developments of Web-based interventions, it would be beneficial to synthesize the evidence for characteristics of effective interventions in CYP to minimize the risk of developing inadequate and ineffective interventions.

A preliminary search conducted in PROSPERO, the Cochrane Database of Systematic Reviews, and the Joanna Briggs Institute (JBI) Database of Systematic Reviews and Implementation Reports indicated that there are no systematic reviews in progress or already published on CYP with NDDs.

\section{Objectives}

The objective of this review was to evaluate the effectiveness of Web-based interventions for CYP with NDDs and conduct a meta-analysis of the most effective intervention characteristics (eg, therapist-supported vs stand-alone) with the aim of informing the future development of technologies. The findings will also be useful to health care providers, commissioners, and clinicians in informing future clinical developments in the delivery of care.

\section{Methods}

The systematic review was registered on PROSPERO (registration number: CRD42018108824) and conducted in accordance with the JBI methodology for systematic reviews of effectiveness evidence.

\section{Search Strategy}

An initial limited scoping search of Medical Literature Analysis and Retrieval System Online (MEDLINE) was undertaken to identify relevant articles. The text words contained in the titles and abstracts of relevant articles and the index and Medical Subject Headings terms describing the articles were used to 
develop a full search strategy, which was then tailored for each included information source (see Multimedia Appendix 1 for full search strategy). Search terms were related to NDDs, Web-based interventions, and adolescence.

A total of 6 electronic databases-including PsycINFO, PubMed, EMBASE, Cochrane Central Register of Controlled Trials, Web of Science, and MEDLINE-were searched in August and September 2018. One trial register (ClinicalTrials.gov) was also searched. The reference list of all studies selected for critical appraisal was screened for additional studies, and several specialized journals, publisher websites, and published reviews were hand-searched. As Web-based interventions are a recent development and older interventions will now be obsolete, the year of publication was limited from 2000 to September 5, 2018. There were no restrictions on the language of publication.

Studies were included if they met the following criteria:

1. The intervention aimed to improve the diagnostic symptomology of the targeted NDD as measured by a valid and reliable outcome measure.

2. The intervention was delivered on the Web via a website, a mobile app, social media, an email, or a personal digital assistant. The intervention could include human support in its delivery.

3. The study was an RCT design and published in a peer-reviewed journal. Trial arms needed to consist of an experimental group compared with no treatment and/or another active intervention or treatment as usual (TAU) or waitlist control.

4. The intervention was targeted at a youth population (aged $\leq 18$ years or reported a mean age of $\leq 18$ years) with a diagnosis or suspected diagnosis of the following NDDs: communication disorders (eg, language disorder and stuttering); ASD; ADHD; specific learning disorder (eg, dyslexia and dyscalculia); motor disorders; TD; other NDDs (eg, NDD associated with prenatal alcohol exposure).

These disorders were selected based on the Diagnostic and Statistical Manual of Mental Disorders, Fifth Edition (DSM-5) criteria [3].

Secondary outcomes of interest were comorbid or associated psychological symptomology and any adverse events. Papers had to report on either primary or secondary outcomes of interest to be included in this review. Studies were excluded if the intervention was not delivered on the Web or was primarily aimed at the parent or caregiver. Furthermore, we excluded studies where the participants were diagnosed with IDs as intervention characteristics that meet the needs of children with significant IDs would be difficult to generalize to a youth population as a whole. Moreover, studies on NDDs frequently exclude CYP with any form of learning difficulty because of their unique complexity [18].

Once duplicates were removed $(n=2142)$, a total of 5140 titles and abstracts were retrieved. Titles were initially screened against the eligibility criteria by 1 assessor (screening phase, $\mathrm{n}=4985$ ineligible). Subsequently, 155 titles and abstracts were then screened against the eligibility criteria by 2 independent assessors. Any conflicts concerning eligibility were resolved by group discussion. There was agreement on 7 papers to be included, 121 to be excluded, and 27 papers requiring further discussion. Following a discussion between the assessors, the full text of 19 papers was obtained for further analysis and coding. A consensus was reached among the assessors on 9 papers to be excluded, as they did not meet the eligibility criteria, leaving 10 papers for analysis. Figure 1 shows the Preferred Reporting Items for Systematic Reviews and Meta-analyses flowchart [19]. 
Figure 1. Preferred reporting items for systematic reviews and meta-analyses flowchart outlining the process for systematic review and meta-analysis. NDD: neurodevelopmental disorder; RCT: randomized controlled trial.

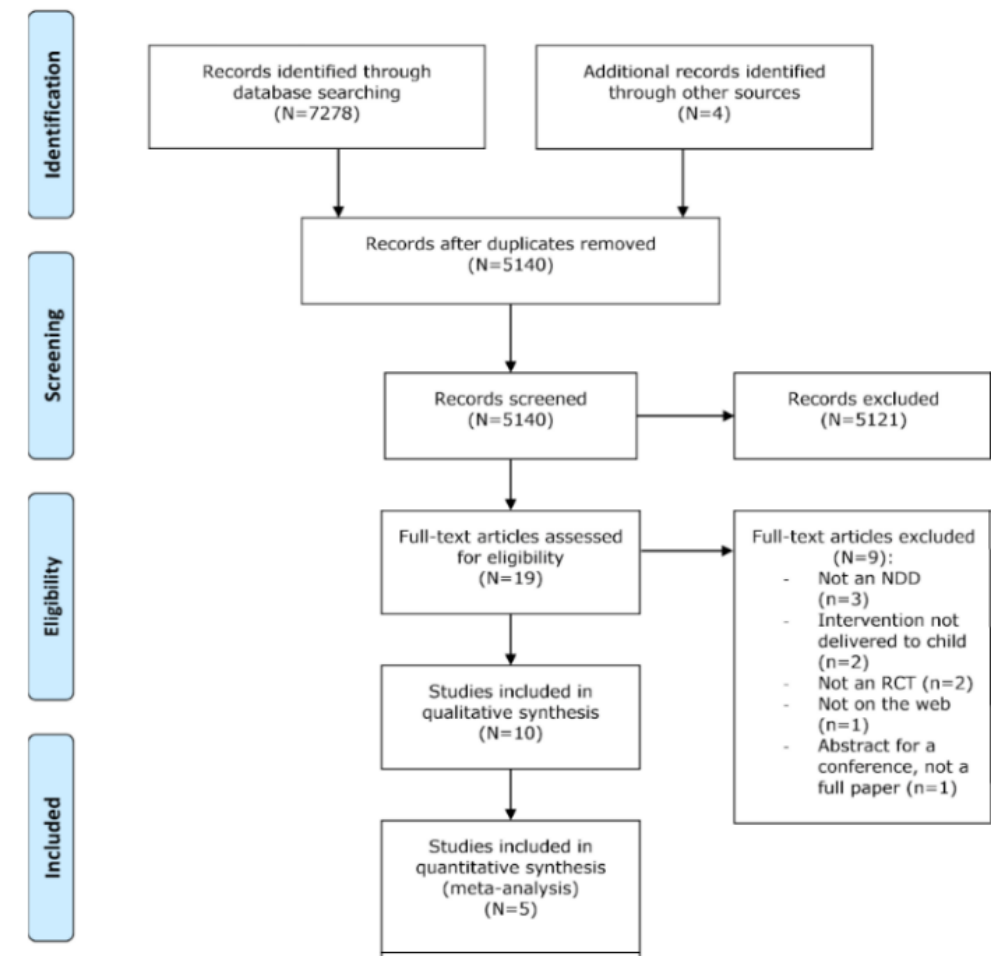

\section{Data Extraction}

The first assessor extracted the following data from all included studies: specific details about the study (authors, year, number of study arms, location, and Web-based program name), population demographics (sample size, age, and gender), study methods, interventions and comparisons, length of treatment or dosage, condition treated (eg, ASD and ADHD), outcome measures, type of analysis (eg, intention-to-treat [ITT]), and primary and secondary outcomes of significance to the review. These data were extracted and inputted into JBI System for the Unified Management, Assessment and Review of Information (SUMARI) software [20]. Missing data were obtained from the manuscripts, and where these data were not documented, the primary authors were contacted for relevant information.

\section{Assessment of Methodological Quality}

A total of 2 independent assessors examined the methodological quality of included studies using the JBI RCT appraisal tool in JBI SUMARI [20]. Further details on the assessment of quality are provided in Multimedia Appendix 2.

\section{Meta-Analysis}

Continuous variables were examined using standardized mean differences (SMD) with 95\% confidence intervals. Extracted continuous data were tested for normality using skew plots. Random effects meta-analyses were performed to compute overall estimates of treatment outcomes. The effect sizes of the primary studies were presented in a forest plot. Heterogeneity was examined with the $\mathrm{I}^{2}$ statistic [21]. The $\mathrm{I}^{2}$ statistic calculates the degree to which there is heterogeneity, with $25 \%$ suggesting low heterogeneity, $50 \%$ indicating moderate, and $75 \%$ indicating the threshold for high heterogeneity. The $Q$ statistic was also calculated and provides the statistical significance ( $P$ value $<.05)$ of heterogeneity.

In the protocol, subgroup analyses were planned to be conducted according to the main intervention characteristics that were shown to be the most effective, for example, therapist support versus no support and parent component versus no parent component. However, because of the low number of included studies in the review, this was deemed unsuitable and is therefore a deviation from the protocol. All data for the meta-analysis were conducted using JBI SUMARI [20].

\section{Results}

\section{Study Characteristics}

The search generated 10 studies. A total of 5 interventions targeted ASD [22-26], 2 were aimed at CYP with TD [27,28], 1 for ADHD [29], 1 for specific learning disorder (LD) with poor visual-motor integration (VMI) [30], and the other targeting dyscalculia [31]. All but one of the interventions focused on treating the primary diagnosis with the other focusing on treating comorbid anxiety [22]. All studies used the standard RCT design, except for one study, which employed a crossover RCT design [29].

In 5 studies, NDD diagnosis was confirmed by DSM-IV or DSM-5 criteria [23,25-27,29] with the other studies using disorder-specific diagnostic tools [22,24,30,31]. All 10 studies contained 2 trial arms with the intervention being compared with another active intervention, which was not Web-based [27,30,31], TAU, which was either standard therapy or participants were not prevented from using therapy; however they were told not to use any apps designed for ASD therapeutic use [23,26,29] or waitlist control [22,24,25,28]. A summary of the characteristics of each study is shown in Table 1. 
Table 1. Characteristics of included studies.

\begin{tabular}{|c|c|c|c|c|c|}
\hline Study & $\begin{array}{l}\text { Design, number of } \\
\text { arms (N per arm), } \\
\text { sample size and } \\
\text { study location }\end{array}$ & $\begin{array}{l}\text { Sample demograph- } \\
\text { ics and condition } \\
\text { treated }\end{array}$ & $\begin{array}{l}\text { Control or com- } \\
\text { parator group }\end{array}$ & Outcome measures & $\begin{array}{l}\text { Summary of main findings or effect of } \\
\text { intervention }\end{array}$ \\
\hline $\begin{array}{l}\text { Conaughton et al, } \\
2017[22]\end{array}$ & $\begin{array}{l}\text { Randomized con- } \\
\text { trolled trial (RCT) } 2 \\
\text { arms: Interven- } \\
\text { tion }=21 \text {, control } \\
\text { group }=21, \mathrm{~N}=42, \\
\text { Australia }\end{array}$ & $\begin{array}{l}\text { Children }(8-12 \\
\text { years; mean } 9.74 ; \\
85.7 \% \text { male) with } \\
\text { high-functioning } \\
\text { autism spectrum } \\
\text { disorder and an } \\
\text { anxiety disorder }\end{array}$ & $\begin{array}{l}\text { Waitlist control } \\
\text { (WLC) }\end{array}$ & $\begin{array}{l}\text { Anxiety Disorders Inter- } \\
\text { view Schedule: parent } \\
\text { and child, Children's } \\
\text { Global Assessment } \\
\text { Scale, Child Behaviour } \\
\text { Checklist, Spence Chil- } \\
\text { dren's Anxiety } \\
\text { Scale-child, satisfaction } \\
\text { with treatment }\end{array}$ & $\begin{array}{l}9.5 \% \text { of the intervention group versus } \\
0 \% \text { of the WLC group had lost all anxi- } \\
\text { ety diagnoses at postassessment, with } \\
14.3 \% \text { of the intervention group being } \\
\text { free of all anxiety diagnoses at } 3 \text {-month } \\
\text { follow-up; the intervention had a positive } \\
\text { effect }\end{array}$ \\
\hline $\begin{array}{l}\text { Esposito et al, } \\
2017 \text { [23] }\end{array}$ & $\begin{array}{l}\text { RCT } 2 \text { arms: Inter- } \\
\text { vention }=15 \text {, control } \\
\text { group }=15, \mathrm{~N}=30, \\
\text { Europe }\end{array}$ & $\begin{array}{l}\text { Children (2-5 } \\
\text { years; mean 3.92; } \\
90 \% \text { male) with } \\
\text { Autism Spectrum } \\
\text { Disorder (ASD) } \\
\text { who followed face- } \\
\text { to-face (F2F) ap- } \\
\text { plied behavior } \\
\text { analysis (ABA) } \\
\text { treatment }\end{array}$ & $\begin{array}{l}\text { Treatment as usu- } \\
\text { al (TAU) }\end{array}$ & $\begin{array}{l}\text { Measured attention, im- } \\
\text { itation of actions with } \\
\text { objects, receptive identi- } \\
\text { fication of objects }\end{array}$ & $\begin{array}{l}\text { Intervention group, who had daily prac- } \\
\text { tice of attention and identification of } \\
\text { objects on tablet apps, showed greater } \\
\text { progress within standard ABA therapy } \\
\text { than the TAU group for all } 3 \text { programs } \\
\text { investigated; however, this did not ex- } \\
\text { ceed the significance level (all } P \text { values } \\
>.05 \text { ); the intervention had no effect }\end{array}$ \\
\hline $\begin{array}{l}\text { Fletcher-Watson } \\
\text { et al, } 2016 \text { [24] }\end{array}$ & $\begin{array}{l}\text { RCT } 2 \text { arms: Inter- } \\
\text { vention }=27, \text { control } \\
\text { group }=27, \mathrm{~N}=54, \\
\text { Europe }\end{array}$ & $\begin{array}{l}\text { Children (<6 years; } \\
\text { mean } 4.13 ; 79.6 \% \\
\text { male) with ASD }\end{array}$ & WLC & $\begin{array}{l}\text { The Autism Diagnostic } \\
\text { Observation Schedule, } \\
\text { Brief observation of so- } \\
\text { cial communication } \\
\text { change, MacArthur } \\
\text { Communicative Devel- } \\
\text { opment Inventory } \\
\text { (MCDI), Communica- } \\
\text { tion and Symbolic Be- } \\
\text { haviour Scales-Devel- } \\
\text { opmental Profile, parent } \\
\text { impressions of the app }\end{array}$ & $\begin{array}{l}\text { Change scores on all outcome measures } \\
\text { revealed no significant differences be- } \\
\text { tween intervention and WLC groups (all } \\
P \text { values }>.05 \text { ); the intervention had no } \\
\text { effect }\end{array}$ \\
\hline $\begin{array}{l}\text { Fridenson-Hayo } \\
\text { et al, } 2017 \text { [25] }\end{array}$ & $\begin{array}{l}\text { RCT } 2 \text { arms: Inter- } \\
\text { vention }=43 \text {, control } \\
\text { group }=40, N=83 \text {, } \\
\text { Europe }\end{array}$ & $\begin{array}{l}\text { Children (6-9 } \\
\text { years; mean } 7.29 \text {; } \\
79.5 \% \text { male) with } \\
\text { ASD }\end{array}$ & WLC & $\begin{array}{l}\text { Emotion recognition } \\
\text { (ER) tasks, Wechsler } \\
\text { Intelligence Scale for } \\
\text { Children or Wechsler } \\
\text { Primary and Preschool } \\
\text { Scale of Intelligence, } \\
\text { Social Responsiveness } \\
\text { Scale, Vineland Adap- } \\
\text { tive Behaviour Scales } \\
\text { (VABS-II) }\end{array}$ & $\begin{array}{l}\text { Pairwise comparisons for the time by } \\
\text { group interaction revealed that signifi- } \\
\text { cant improvement over time was found } \\
\text { on all ER tasks for the intervention group } \\
\text { but not for the WLC group; the interven- } \\
\text { tion had a positive effect }\end{array}$ \\
\hline $\begin{array}{l}\text { Whitehouse et al, } \\
2017 \text { [26] }\end{array}$ & $\begin{array}{l}\text { RCT } 2 \text { arms: Inter- } \\
\text { vention=41), control } \\
\text { group }=39, \mathrm{~N}=80, \\
\text { Australia }\end{array}$ & $\begin{array}{l}\text { Children (<4 years; } \\
\text { mean } 3.32 ; 78.7 \% \\
\text { male) with ASD }\end{array}$ & TAU & $\begin{array}{l}\text { The Autism Treatment } \\
\text { Evaluation Checklist } \\
\text { (ATEC), The Mullen } \\
\text { Scales of Early Learn- } \\
\text { ing, VABS-II, MCDI, } \\
\text { Communication and } \\
\text { Symbolic Behaviour } \\
\text { Scales, Repetitive Be- } \\
\text { haviour Scale-Revised } \\
\text {, Behaviour Flexibility } \\
\text { Rating Scale }\end{array}$ & $\begin{array}{l}\text { No significant differences were observed } \\
\text { between groups for any of the } 4 \text { ATEC } \\
\text { subscales at either the } 3 \text { - or } 6 \text {-month as- } \\
\text { sessments, although the } 3 \text {-month commu- } \\
\text { nication subscale showed a trend toward } \\
\text { greater improvement in the intervention } \\
\text { group, } 2.1 \text { units ( } 95 \% \text { CI } 4.5 \text { to } 0.3 \text {; } \\
P=.08 \text { ); the intervention had no effect }\end{array}$ \\
\hline
\end{tabular}




\begin{tabular}{|c|c|c|c|c|c|}
\hline Study & $\begin{array}{l}\text { Design, number of } \\
\text { arms (N per arm), } \\
\text { sample size and } \\
\text { study location }\end{array}$ & $\begin{array}{l}\text { Sample demograph- } \\
\text { ics and condition } \\
\text { treated }\end{array}$ & $\begin{array}{l}\text { Control or com- } \\
\text { parator group }\end{array}$ & Outcome measures & $\begin{array}{l}\text { Summary of main findings or effect of } \\
\text { intervention }\end{array}$ \\
\hline $\begin{array}{l}\text { Himle et al, } 2012 \\
\text { [27] }\end{array}$ & $\begin{array}{l}\text { RCT } 2 \text { arms: Inter- } \\
\text { vention }=10 \text {, com- } \\
\text { parator group }=10 \text {, } \\
\mathrm{N}=20 \text {, North Ameri- } \\
\text { ca }\end{array}$ & $\begin{array}{l}\text { Children (8-17 } \\
\text { years, mean } 11.6 \text {, } \\
94 \% \text { male) with tic } \\
\text { disorders (TD) or } \\
\text { chronic tic disor- } \\
\text { ders (CTD) }\end{array}$ & $\begin{array}{l}\text { F2F Comprehen- } \\
\text { sive Behavioural } \\
\text { Intervention for } \\
\text { Tics }\end{array}$ & $\begin{array}{l}\text { Yale Global Tic Severi- } \\
\text { ty Scale (YGTSS), } \\
\text { Clinical Global Impres- } \\
\text { sion-Improvement } \\
\text { Scale (CGI-I), Parent } \\
\text { Tic Questionnaire } \\
\text { (PTQ), Treatment Ac- } \\
\text { ceptability Question- } \\
\text { naire (TAQ) }\end{array}$ & $\begin{array}{l}\text { The videoconferencing group showed a } \\
\text { mean YGTSS reduction of } 6.4 \text { points } \\
\text { versus } 4.2 \text { points for the F } 2 \mathrm{~F} \text { group at } \\
\text { follow-up; both interventions were effec- } \\
\text { tive in reducing tics however, there was } \\
\text { a slightly better effect on the intervention } \\
\text { group at both post-treatment and follow- } \\
\text { up compared with the F } 2 \mathrm{~F} \text { group }\end{array}$ \\
\hline $\begin{array}{l}\text { Ricketts et al, } \\
2016[28]\end{array}$ & $\begin{array}{l}\text { RCT } 2 \text { arms: Inter- } \\
\text { vention }=12 \text {, control } \\
\text { group }=8, \mathrm{~N}=20 \text {, } \\
\text { North America }\end{array}$ & $\begin{array}{l}\text { Children }(8-16 \\
\text { years; mean } 12.16 \text {; } \\
64.9 \% \text { male) with } \\
\text { TD or CTD }\end{array}$ & WLC & $\begin{array}{l}\text { YGTSS, CGI-I, PTQ, } \\
\text { Children's Perception } \\
\text { of Therapeutic Relation- } \\
\text { ship, Client Satisfaction } \\
\text { Questionnaire, TAQ, } \\
\text { Videoconferencing Sat- } \\
\text { isfaction Questionnaire }\end{array}$ & $\begin{array}{l}\text { In the intervention group, there was a } \\
\text { statistically significant decrease of } 7.25 \\
\text { points in YGTSS total scores from } \\
\text { baseline to postassessment. In the WLC } \\
\text { group, the } 1.75 \text {-point decrease on the } \\
\text { YGTSS total scores from baseline to } \\
\text { postassessment was not significant; the } \\
\text { intervention had a positive effect }\end{array}$ \\
\hline $\begin{array}{l}\text { Bul et al, } 2016 \\
\text { [29] }\end{array}$ & $\begin{array}{l}\text { Crossover RCT } 2 \\
\text { arms: Interven- } \\
\text { tion }=88 \text {, comparator } \\
\text { group }=82, \mathrm{~N}=170, \\
\text { Europe }\end{array}$ & $\begin{array}{l}\text { Children ( } 8-12 \\
\text { years; mean } 9.85 ; \\
80.6 \% \text { male) with } \\
\text { attention deficit } \\
\text { hyperactivity disor- } \\
\text { der }\end{array}$ & $\begin{array}{l}\text { TAU crossover } \\
\text { group }\end{array}$ & $\begin{array}{l}\text { Time management } \\
\text { questionnaire, Be- } \\
\text { haviour Rating Invento- } \\
\text { ry of Executive Func- } \\
\text { tion (subscale plan or } \\
\text { organize), Social Skills } \\
\text { Rating System (sub- } \\
\text { scale cooperation), It's } \\
\text { About Time Question- } \\
\text { naire, self-efficacy, sat- } \\
\text { isfaction }\end{array}$ & $\begin{array}{l}\text { Intervention group achieved significantly } \\
\text { greater improvements on the primary } \\
\text { outcome of time management skills } \\
\text { compared with TAU crossover group } \\
\text { (parent-reported; } P=.004 \text { ) and on sec- } \\
\text { ondary outcomes of responsibility (par- } \\
\text { ent-reported; } P=.04 \text { ), and working } \\
\text { memory (parent-reported; } P=.02 \text { ); the } \\
\text { intervention had a positive effect }\end{array}$ \\
\hline $\begin{array}{l}\text { Coutinho et al, } \\
2017 \text { [30] }\end{array}$ & $\begin{array}{l}\text { RCT } 2 \text { arms: Inter- } \\
\text { vention=10, com- } \\
\text { parator group=10, } \\
\mathrm{N}=20 \text {, North Ameri- } \\
\text { ca }\end{array}$ & $\begin{array}{l}\text { School-aged chil- } \\
\text { dren (4-7 years; } \\
\text { mean } 6.18 ; 12 \\
\text { males) with a spe- } \\
\text { cific learning disor- } \\
\text { der such as dys- } \\
\text { praxia or speech } \\
\text { delay with poor vi- } \\
\text { sual-motor integra- } \\
\text { tion (VMI) skills }\end{array}$ & $\begin{array}{l}\text { Traditional occu- } \\
\text { pational therapy } \\
\text { sessions }\end{array}$ & $\begin{array}{l}\text { Beery VMI, Miller } \\
\text { function and participa- } \\
\text { tion scales, intervention } \\
\text { appreciation scale }\end{array}$ & $\begin{array}{l}\text { There were some improvements in VMI } \\
\text { skills in both groups; however, the find- } \\
\text { ing was not statistically significant; the } \\
\text { intervention had no effect }\end{array}$ \\
\hline $\begin{array}{l}\text { De Castro et al, } \\
2014[31]\end{array}$ & $\begin{array}{l}\text { RCT } 2 \text { arms: Inter- } \\
\text { vention }=13 \text {, control } \\
\text { group }=13, \mathrm{~N}=26 \text {, } \\
\text { South America }\end{array}$ & $\begin{array}{l}\text { Primary school } \\
\text { children }(7-10 \\
\text { years; mean } 8.11 \text {; } \\
16 \text { male) with } \\
\text { dyscalculia }\end{array}$ & $\begin{array}{l}\text { Traditional teach- } \\
\text { ing techniques }\end{array}$ & $\begin{array}{l}\text { Scholastic Performance } \\
\text { Test }\end{array}$ & $\begin{array}{l}\text { The intervention using the virtual envi- } \\
\text { ronment yielded a significant score im- } \\
\text { provement }(P<.001) \text { with an average } \\
\text { score improvement of } 5.09 \text { posttest, } \\
\text { whereas the control group did not show } \\
\text { a statistically significant score improve- } \\
\text { ment }(P=.05) \text {; the intervention had a } \\
\text { positive effect }\end{array}$ \\
\hline
\end{tabular}

\section{Modality, Location, and Duration of Intervention}

A total of 4 interventions were delivered via apps [23,24,26,30], 2 were serious games [25,29], 2 used videoconferencing [27,28], 1 was a virtual environment with playable games [31], and the other was a Web-based CBT intervention [22]. Most of the interventions were accessed from participants' own homes, except 3 studies where participants were based in a rehabilitation center [30], school [31], and hospital or clinic setting [27]. Interventions either had a varying range of components (ie, tasks to be completed) - 2 [24,29], 3 [23], and 4 [25,26] components-or sessions, ranging from 8 [27,28] to 10 $[22,30,31]$ sessions. All trials instructed participants on an optimum length of time to access the intervention: ranging from 5 min per day or 10 min every other day [24], 20 min daily [26] and $30 \mathrm{~min}$ per day [23] to approximately 2 hours per week [25], one 60-min session per week [22], 2 40-min sessions per week [30], 60 min twice per week [31], and 65 min 3 times per week [29]. The 2 trials comparing Web-based comprehensive behavioral intervention for tics (CBIT) stated that participants received 6 weekly sessions followed by 2 biweekly sessions [27] and 2 1.5-hour sessions followed by 61 -hour sessions [28]. The intervention delivery period ranged from 4 [23] to 24 weeks [26], with a median length of 10 weeks. 
A summary of the characteristics of each intervention is shown in Table 2.

Table 2. Characteristics of interventions

\begin{tabular}{|c|c|c|c|c|}
\hline Study & Intervention, modality, and aim of the intervention & Length or dosage, follow-ups & Therapist supported & Parent component \\
\hline $\begin{array}{l}\text { Conaughton et al } \\
\text { [22] }\end{array}$ & $\begin{array}{l}\text { Internet trans diagnostic } \mathrm{CBT}^{\mathrm{a}} \text { intervention aimed } \\
\text { at improving comorbid anxiety symptoms }\end{array}$ & $\begin{array}{l}10 \text { weeks, } 10 \text { sessions-one } \\
60 \text {-min session per week }\end{array}$ & Yes & Yes \\
\hline Esposito et al [23] & $\begin{array}{l}\text { Tablet apps aimed at improving attention and } \\
\text { identification of objects }\end{array}$ & $\begin{array}{l}4 \text { weeks, } 3 \text { app compo- } \\
\text { nents-30 min daily }\end{array}$ & Yes & Yes \\
\hline $\begin{array}{l}\text { Fletcher-Watson } \\
\text { [24] }\end{array}$ & $\begin{array}{l}\text { iPad app aimed to improve social communication } \\
\text { skills }\end{array}$ & $\begin{array}{l}\text { 2-months, } 2 \text { parts }-5 \text { min per } \\
\text { day, or } 10 \text { min every other } \\
\text { day }\end{array}$ & No & No \\
\hline $\begin{array}{l}\text { Fridenson-Hayo et } \\
\text { al [25] }\end{array}$ & $\begin{array}{l}\text { An internet-based serious game aimed at improv- } \\
\text { ing emotion recognition }\end{array}$ & $\begin{array}{l}8-12 \text { weeks, } 4 \text { components—-2 } \\
\text { hours per week }\end{array}$ & No & Yes \\
\hline $\begin{array}{l}\text { Whitehouse et al } \\
\text { [26] }\end{array}$ & $\begin{array}{l}\text { iPad app aimed at improving developmental skills } \\
\text { relevant to autism }\end{array}$ & $\begin{array}{l}6 \text { months, } 4 \text { components- } 20 \\
\text { min per day }\end{array}$ & No & Yes \\
\hline Himle et al [27] & $\begin{array}{l}\text { Internet-accessed videoconference aimed at im- } \\
\text { proving tic severity }\end{array}$ & $\begin{array}{l}10 \text { weeks }-6 \text { weekly sessions } \\
\text { followed by } 2 \text { biweekly ses- } \\
\text { sions }\end{array}$ & Yes & Yes \\
\hline Ricketts et al [28] & $\begin{array}{l}\text { Internet-accessed videoconference (Skype) aimed } \\
\text { at improving tic severity }\end{array}$ & $\begin{array}{l}10 \text { weeks- } 21.5 \text {-hour ses- } \\
\text { sions followed by } 61 \text {-hour } \\
\text { sessions }\end{array}$ & Yes & Yes \\
\hline Bul et al [29] & $\begin{array}{l}\text { An internet-based serious game aimed at improv- } \\
\text { ing time management and planning skills }\end{array}$ & $\begin{array}{l}10 \text { weeks, } 2 \text { game compo- } \\
\text { nents - } 65 \text { min approximately } \\
3 \text { times per week }\end{array}$ & No & No \\
\hline Coutinho et al [30] & $\begin{array}{l}\text { Multiple iPad apps aimed at improving visual } \\
\text { motor skills }\end{array}$ & $\begin{array}{l}10 \text { weeks, minimum of } 8 \text { and } \\
\text { maximum of } 12 \text { sessions-2 } \\
40 \text {-min sessions per week }\end{array}$ & No & No \\
\hline De Castro et al [31] & $\begin{array}{l}\text { Internet-accessed virtual environment aimed at } \\
\text { improving mathematical skills }\end{array}$ & $\begin{array}{l}5 \text { weeks, } 10 \text { sessions }-60 \mathrm{~min} \\
\text { twice a week }\end{array}$ & No & No \\
\hline
\end{tabular}

${ }^{\mathrm{a} C B T}$ : cognitive behavioral therapy.

\section{Use of Human and Technical Support}

In total, 4 interventions were therapist assisted [22,23,27,28]; however, all these differed in the level of involvement of the therapist within the interventions. The contacts ranged from once weekly contact [22] 2 hours per week [23], and the 2 trials of CBIT were exclusively therapist-delivered [27,28].

One of the major factors that developers need to consider when creating Web-based intervention is the ease with which nontechnologically advanced individuals can access and use the program. Thus, it is crucial to provide technical support as and when needed. In total, 7 of the 10 included studies reported the use of technical support. In 2 trials [22,28], participants had weekly access to a therapist who was able to offer any technical assistance within the sessions. One trial [30] took place within a rehabilitation center with an occupational therapist (OT) constantly present to offer any assistance. Two trials reported the use of monitoring phone calls from research personnel to check for any issues, which were offered either fortnightly [26] or once a week [25]. In both of these trials, parents were also encouraged to contact research staff with any queries or issues in between monitoring calls. In one trial [27], research personnel were available to manage any technical difficulties. In the other trial [23], parents were fully trained in the apps by research staff and were taught how to handle technical difficulties.

\section{Participant Characteristics}

A total of 545 participants consented and were randomized to a trial arm. Sample sizes ranged from 20 [27,28,30] to 170 [29] participants. A total of 4 trials had sample sizes of $>50$ participants [24-26,29]. Overall, 523 participants were explicitly included in analyses. A total of 5 studies stated that the analysis was conducted on participants who completed pre- and postintervention measures only [23,25,27,30,31], whereas 5 conducted ITT analyses [22,24,26,28,29]. All 10 trials reported participant dropout or withdrawal data, with dropout rates ranging from $0 \%[23,28,31]$ to $18 \%(n=31)$ of the sample [29]. Reasons for participant withdrawal included lack of motivation or disinterest [25,29], lack of enjoyment with the intervention [24,26], and personal reasons [26].

In the 10 trials, participants ranged in age from 2 to 17 years, with a mean age ranging from 3.32 to 12.16 years. Males were the majority in all studies, with gender balance varying from $62.5 \%$ [31] to $94 \%$ [27] of the sample being male. A total of 4 trials were conducted in Europe [23-25,29], 3 in North America [27,28,30], 2 in Australia [22,26], and 1 in South America [31].

\section{Provider Characteristics}

Most of the trials recruited participants from clinics [22-25,29], with 3 studies $[25,26,28]$ recruiting via advertisements and 1 study [28] recruiting participants through solicitations mailed 
to health care professionals. One study [26] recruited participants through referrals from diagnosing clinicians, and another study [22] utilized referrals through general practitioners, mental health professionals, school guidance officers, teachers, parents, and media publicity.

\section{Adverse Events and Outcome Measures}

Only 1 study [29] explicitly stated that they recorded and reported adverse events. The crossover trial investigating the effects of a serious game as an adjunct to TAU for children with ADHD reported 10 adverse events in the trial that could be related to the intervention, and parents, teachers, or participants themselves reported these. Adverse events were registered as mild $(n=5)$ or moderate $(n=5)$ in severity and examples included pain in the fingers, irritability, and headache. One participant could not concentrate at school and therefore discontinued from the trial because of this adverse event; however, no serious adverse events were reported.

It was estimated that the outcome measurement battery ranged from 16 [24] to 175 items [26] at each time point of the studies. The estimated median number of questions administered to participants was 56 items (see Multimedia Appendix 2 for more details).

\section{Methodological Quality and Risk of Bias}

The JBI Critical Appraisal Checklist for RCTs provided a framework for scoring the quality of the included studies by addressing different aspects of the research such as randomization, allocation concealment, blinding, and follow-up data. The methodological quality of included studies was felt to be moderate, mostly because of trials providing insufficient details or being unclear in their reporting (see Table 3). Only 5 of 10 studies reported their randomization methodology $[22,24,28-30]$. Blinding was the main issue of quality in included studies. A total of 6 trials stated that participants were not blind to treatment assignment with the other 4 trials being unclear in their reporting. Only 1 study [23] reported that those delivering treatments were blind to treatment assignment with the others stating researchers delivering treatment were either not blinded or it was unclear. Half of the trials [22-24,26,27] reported outcome assessors were blind to treatment assignment with all of these studies employing independent researchers to carry out assessments. 
Table 3. Critical appraisal of included studies.

\begin{tabular}{|c|c|c|c|c|c|c|c|c|c|c|c|c|c|}
\hline Study & $\mathrm{Q} 1^{\mathrm{a}}$ & $\mathrm{Q} 2^{\mathrm{b}}$ & $\mathrm{Q} 3^{\mathrm{c}}$ & $\mathrm{Q} 4^{\mathrm{d}}$ & $\mathrm{Q}^{\mathrm{e}}$ & $\mathrm{Q6}^{\mathrm{f}}$ & $\mathrm{Q}^{\mathrm{g}}$ & $\mathrm{Q}^{\mathrm{h}}$ & $\mathrm{Q}^{\mathrm{i}}$ & Q10 ${ }^{\mathrm{j}}$ & $\mathrm{Q} 11^{\mathrm{k}}$ & Q12 ${ }^{1}$ & $\mathrm{Q} 13^{\mathrm{m}}$ \\
\hline $\begin{array}{l}\text { Conaughton } \\
\text { et al [22] }\end{array}$ & Yes & Yes & Yes & Unclear & No & Yes & No & Yes & Yes & No & Yes & Yes & Yes \\
\hline $\begin{array}{l}\text { Esposito et } \\
\text { al [23] }\end{array}$ & Unclear & Unclear & Yes & Unclear & Yes & Yes & Yes & Yes & Yes & Yes & Yes & Yes & Yes \\
\hline $\begin{array}{l}\text { Fletcher- } \\
\text { Watson et } \\
\text { al [24] }\end{array}$ & Yes & Yes & Yes & No & Unclear & Yes & Yes & Yes & Yes & Yes & Yes & Yes & Yes \\
\hline $\begin{array}{l}\text { Fridenson- } \\
\text { Hayo et al } \\
{[25]}\end{array}$ & Unclear & Unclear & Yes & No & No & Unclear & Yes & Yes & Unclear & Yes & Yes & Yes & Yes \\
\hline $\begin{array}{l}\text { White- } \\
\text { house et al } \\
{[26]}\end{array}$ & Unclear & Unclear & Yes & No & No & Yes & Yes & Yes & Yes & Yes & Yes & Yes & Yes \\
\hline $\begin{array}{l}\text { Himle et al } \\
{[27]}\end{array}$ & Unclear & Unclear & Yes & No & No & Yes & Yes & Yes & No & Yes & Yes & Yes & Yes \\
\hline $\begin{array}{l}\text { Ricketts et } \\
\text { al [28] }\end{array}$ & Yes & Unclear & Yes & No & No & Unclear & Yes & Yes & Yes & Yes & Yes & Yes & Yes \\
\hline $\begin{array}{l}\text { Bul et al } \\
\text { [29] }\end{array}$ & Yes & No & Yes & No & Unclear & Unclear & Yes & Yes & Yes & Yes & Yes & Yes & Yes \\
\hline $\begin{array}{l}\text { Coutinho } \\
\text { et al [30] }\end{array}$ & Yes & Unclear & Yes & Unclear & Unclear & Unclear & Yes & Yes & Yes & Yes & Yes & Yes & Yes \\
\hline $\begin{array}{l}\text { De Castro } \\
\text { et al [31] }\end{array}$ & Unclear & Unclear & Yes & Unclear & Unclear & Unclear & Yes & Yes & Unclear & Yes & Yes & Yes & Yes \\
\hline $\begin{array}{l}\text { Number } \\
\text { that met } \\
\text { the criteria } \\
(\%)\end{array}$ & 50 & 20 & 100 & 0 & 10 & 50 & 90 & 100 & 70 & 90 & 100 & 100 & 100 \\
\hline
\end{tabular}

${ }^{\mathrm{a}} \mathrm{Q} 1$ : True randomization.

${ }^{\mathrm{b}} \mathrm{Q}$ : Allocation concealed.

${ }^{\mathrm{c}} \mathrm{Q}$ : Treatment groups similar at the baseline.

${ }^{\mathrm{d}} \mathrm{Q}$ : Participants blind to treatment.

${ }^{\mathrm{e}} \mathrm{Q} 5$ : Those delivering intervention blind to treatment.

${ }^{f}$ Q6: Outcome assessors blind to treatment.

${ }^{\mathrm{g}} \mathrm{Q}$ : Treatment groups treated identically.

${ }^{\mathrm{h}} \mathrm{Q} 8$ : Follow-up complete and if not, differences between groups adequately described and analyzed.

${ }^{\mathrm{i}} \mathrm{Q}$ : Participants analyzed in the groups to which they were randomized.

${ }^{\mathrm{j}} \mathrm{Q} 10$ : Outcomes measured in the same way for groups.

${ }^{\mathrm{k}} \mathrm{Q} 11$ : Outcomes measured reliably.

${ }^{1} \mathrm{Q} 12$ : Appropriate statistical analysis.

${ }^{\mathrm{m}} \mathrm{Q} 13$ : Appropriateness of trial design and any deviations from RCT design accounted for.

\section{Effectiveness of Web-Based Interventions}

Of 10 trials, 6 trials found that Web-based interventions were effective in reducing NDDs or associated symptoms in CYP [22,25,27-29,31]; 2 were serious games, 2 were delivered by videoconferencing, 1 was a virtual environment, and the other was an internet-delivered CBT intervention. Targeted NDD conditions of the effective interventions included ASD [22,25], TD [27,28], ADHD [29], and dyscalculia [31]. All but 2 of the effective interventions were delivered over a period of 10 weeks, and these 2 were delivered over 5 weeks with 10 sessions [31] and 8 to 12 weeks with 4 components [25]. The 4 trials, which did not find that Web-based interventions had an effect on NDD symptoms, were all delivered by apps [23,24,26,30]. All but one of these was designed for CYP with ASD, the other being designed for specific LD with VMI [30].

\section{Primary Outcomes}

Of 10 interventions, 4 interventions in the included studies were aimed at a youth population with ASD; however, just one [25] of these trials found that Web-based interventions were effective. In the study by Fridenson-Hayo et al [25], children with ASD who received an internet-based serious game improved in ER tasks compared with the WLC group who received TAU. A total of 3 studies $[23,24,26]$ comparing iPad or tablet apps with 
WLC/TAU groups for children with ASD found no difference in outcome between the groups.

Both studies evaluating the effectiveness of internet-delivered CBIT via videoconferencing for young people with TD/CTD showed it could be effective for reducing tic symptomology. Overall, the studies were of similar design but used different comparators with Himle et al [27] using F2F CBIT in their study whereas WLC was utilized in a study by Ricketts et al [28]. The YGTSS was the main primary measure in both trials.

There were 3 other studies that looked to improve primary symptoms in CYP, and these were targeted at CYP with NDDs other than ASD or TD. One study showed improvements in time management skills for children with ADHD [29], and another study found improvements in mathematical skills for children with dyscalculia [31]. The other study found no effect in VMI scores [30]. Secondary outcomes are discussed in Multimedia Appendix 2.

\section{Satisfaction or Acceptability of the Intervention}

A total of 4 trials included participant satisfaction measures [22,24,26,29] and 2 trials administered participant acceptability questionnaires [27,28]. In the study by Bul et al [29], both children and parents reported moderate to high satisfaction with receiving the serious game intervention. In the study by Conaughton et al [22], children and parents reported moderate levels of satisfaction following treatment. In the study by Fletcher-Watson et al [24], parents gave verbal comments on the app and what they perceived to be their child's response to it. Replies were categorized as Positive, Mixed, or Negative, and there were positive responses to questions on overall experience with the app, whether the child and parent liked the app, and ease of use. In the other study to measure participant satisfaction [26], caregivers of children in the Therapy Outcomes By You (TOBY) intervention group were asked to list up to 3 features that they liked or disliked about the app. The most frequent like statement related to TOBY providing a helpful therapy-planning tool. Other common statements were that TOBY was easy to use and that the app provided a positive learning experience for their child with an attractive structure and layout. The most common dislike statement was that the offline iPad activities were too time-consuming to prepare. The 2 trials evaluating VC administered CBIT [27,28] gathered acceptability ratings from participants. In both studies, children and parents gave high acceptability ratings for the intervention.

\section{Meta-Analysis}

In studies that used a valid and reliable outcome measurement of NDD and associated symptoms, a meta-analysis was undertaken. All outcomes were continuous and scale-based and were extracted as endpoint average scores with lower scores indicating less severe symptomology. The outcomes combined for the meta-analysis were anxiety [22], social communication [24], developmental skills [26], and tic severity [27,28]. Negative SMD values support the intervention in the presented analyses. Figure 2 shows the forest plot for the data.

Figure 2. Forest plot of postintervention neurodevelopmental disorder outcomes for intervention compared with controls.

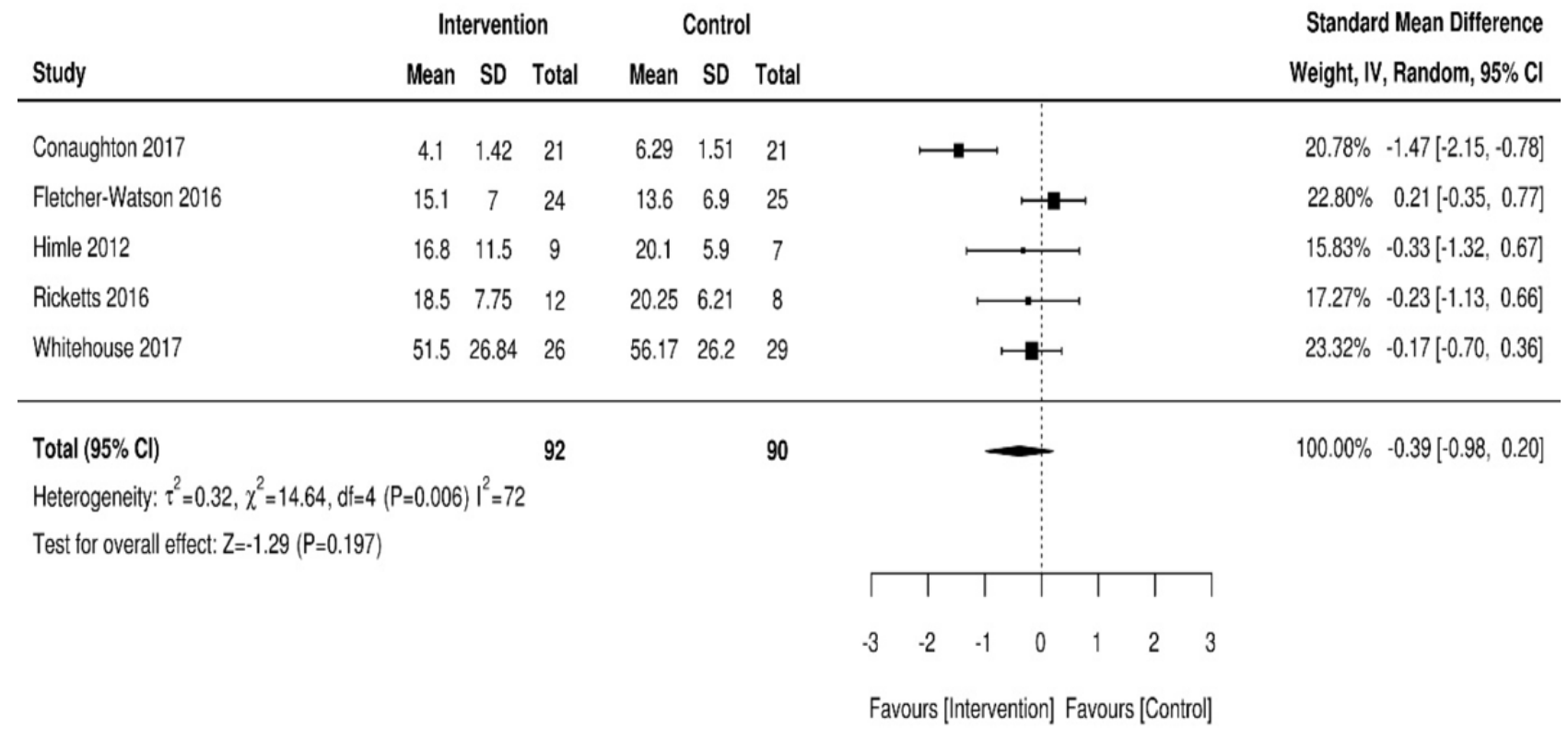

A total of 5 trials investigated the effects of Web-based interventions on NDD symptoms using a valid, standardized outcome measure to explore symptom reduction. Within the 5 trials, neither intervention nor control was favored, with a high level of heterogeneity detected: 182/545 (33.4\%), 5 RCTs, pooled $\mathrm{SMD}=-0.39 ; 95 \% \mathrm{CI}-0.98$ to $0.20 ; \mathrm{Z}=-1.29 ; P=.19$ $\left(\mathrm{I}^{2}=72 \% ; P=.006\right)$.

\section{Discussion}

\section{Principal Findings}

We set out to evaluate whether RCT evidence showed Web-based interventions were effective for CYP with NDDs and/or associated symptoms. Our review retrieved 10 studies in total. A further meta-analysis was conducted on 5 of the 10 studies. Most of the interventions targeted ASD in CYP. Overall, 
the meta-analysis indicated no difference between the intervention and control groups; however, with 6 of the 10 retrieved papers showing a positive effect, the findings suggest that Web-based interventions can be effective in reducing NDD symptoms in CYP. However, the evidence is inconclusive owing to the limited number of retrieved studies and small sample sizes in included trials. The findings indicate the need for further research in the use of Web-based interventions aimed at CYP with NDDs.

Furthermore, one of our initial aims was to evaluate the main characteristics of effective Web-based interventions. A parent component as an adjunct to the main intervention was utilized in 4 of the 6 effective trials, indicating the potential importance of assisted interventions and in line with previous research $[16,32,33]$. Having a parent component within the interventions is unsurprising given the young age of participants in the included studies. It is more likely that younger children will require some form of parental assistance with digitized interventions and, more generally, therapeutic interventions. Indeed, Thirwall et al [34] found that younger children showed a greater improvement in anxiety symptoms having received a parent-delivered CBT intervention. From this review, it is unclear whether a therapist-supported Web-based intervention is more efficacious than one without, as only half of the effective interventions were therapist supported. Another important characteristic to consider is the length of the intervention. A total of 5 of the 6 effective interventions were delivered over a period of 10 to 12 weeks, with the other having 10 sessions delivered over 5 weeks. This suggests that 10 to 12 weeks/sessions is the optimum length for a Web-based intervention. However, given the high heterogeneity between the Web-based interventions and number of multifaceted aspects to these interventions in this review, caution should be taken when trying to establish certain characteristics that may be relevant in determining effectiveness.

All 4 of the included interventions delivered by apps were unsuccessful in yielding statistically significant outcomes. This suggests apps may not be a promising platform for delivering therapeutic interventions, at least to CYP with NDDs. Indeed, recent systematic reviews [35,36], have shown there is inconclusive evidence on the efficacy of mobile apps utilized as health interventions, despite the high user acceptability ratings of smartphone apps. One interpretation of this finding is that because apps are a new phenomenon-the first mobile apps being developed in 2008 with the advent of Apple's App Store [37]-little is known about their mechanisms of impact, especially in the health care domain. There are over 10,000 mental health apps commercially available [38], with $52 \%$ of smartphone owners using their phones for health purposes and $19 \%$ using health apps [39], it is clear that more high-quality research needs to be conducted. As 3 of the 4 apps that found no effect were targeted at CYP with ASD, another interpretation of this finding could be that apps are an insufficient modality for producing positive outcomes in autism-related disorders. This corroborates the results of a study conducted by Grynszpan et al [40]. They found that adolescents with ASD performed poorly on rich multimedia interfaces, such as apps, as they

lacked the required initiative in organizing information given within the multimodal sources.

Half of the included interventions were delivered to CYP with ASD, and much of the research to date evaluating digital technologies administered to NDDs has focused on ASD [41-43]. A possible explanation for this is that computer technology can help compensate verbal and social interaction difficulties and enable facilitation of exchanges between people with ASD, experts, and others [44]. The vast potential of technology for ASD has been realized by researchers, as technologies can enable new ways of communicating for people with ASD, socializing, and even learning. Despite this, many studies still lack scientific rigor to allow for concrete support for the use of technology in aiding people with ASD [42]. In this review, 2 of the 5 RCTs found that Web-based interventions were effective for CYP with ASD and one of these targeted CYP with HFASD who had a comorbid diagnosis of an anxiety disorder.

The RCTs included in this review were assessed as being of acceptable quality for a review of effectiveness. However, the main methodological issues centered on the lack of blinding of participants and of those delivering treatment. All studies had a control group, which was either active or inactive, with half of the trials using valid, standardized outcome measures. Most trials had low attrition rates thus improving the overall quality of the included studies. Only 1 of the 10 trials explicitly recorded and reported adverse events [29]. They reported on 10 adverse events that could be related to the intervention however, none were regarded as serious. Insufficient reporting of adverse events in psychological treatments has been documented in the literature [45], and it is clear that future trials should be more explicit in their reporting.

\section{Limitations}

Some limitations of the review and meta-analysis need to be considered. A major limitation is the minimal number of studies retrieved meaning that any conclusions drawn from this review must be met with caution. To provide an expansive overview of the effectiveness of Web-based interventions for CYP, we included trials targeting a myriad of NDDs, which may have equilibrated disorder-specific effects of Web-based interventions. As there were very few RCTs evaluating the effectiveness of Web-based interventions in CYP with NDDs, it would have been impractical to carry out a review focusing on 1 NDD only. We could have increased the number of NDDs by also including trials focusing on CYP with learning disabilities; however, this would have further increased the heterogeneity and added to the problems of generalizability owing to the complexity of this particular population. The search was conducted on multiple databases and updated through a repeated search, thus ensuring a comprehensive overview of the topic. A particular strength of this review is that we had 2 independent reviewers screening relevant papers, with discrepancies between the reviewers discussed. This ensured a structured, meticulous approach was undertaken in study selection, therefore, improving review quality.

For the meta-analysis, we could only include data from 5 of the 10 trials, meaning the pool of data from included interventions 
was small and limited the overall power. Moreover, there was a high level of heterogeneity detected in the meta-analysis, which may have been because of the types of comparison with the interventions or differences in baseline symptomology [46]. There is mixed literature on whether a meta-analysis should be conducted at all in the event of high heterogeneity; however, experts recommend using the random effects model $[21,47]$ that was used in this review. Finally, a major strength of this review is that it is based on a priori protocol that decreases the potential for reviewer bias.

When interpreting the findings, some inherent methodological issues of the included studies must also be considered, as methodological flaws of the primary trials can have a considerable impact on the review results. One intrinsic methodological limitation of many therapeutic intervention trials is the lack of blinding of participants and those delivering treatment [48], thus introducing a high risk of bias. As already mentioned, most of the included trials had very small sample sizes, which makes the generalization of findings highly problematic. All interventions used different content and modalities of delivery, which could have affected participant interaction and consequently, effectiveness [49]. Another limitation is with the RCT design itself. Given that the most effective interventions are individualized to the user [17], this is often difficult to assess using an RCT design, meaning the interventions reviewed mostly fell short on this dimension.

Gender balance was a potential issue of bias in included studies, as most of the trials had more male participants than female. However, this is not surprising given that NDDs are more common in males than females [50]. Baseline symptomology was also a potential source of bias, as this may have caused difficulties comparing intervention effectiveness in improving NDD outcomes. Some trials recruited participants with minimal symptoms, whereas others recruited those experiencing high levels of NDD symptoms. Despite these limitations, the overall reporting of the included trials was of a high standard and methodologically sound.

\section{Implications for Practice}

As some of the interventions found positive outcomes, health care professionals working with CYP may want to consider utilizing Web-based and digital resources to support their patients, especially those with tics. The National Health Service (NHS) has already developed improving access to psychological therapy services for young people with mental health problems and is aiming to incorporate this into practice nationwide within the coming years [51]. If this is successful in reducing the burden on health care services and is shown to be cost-effective, this could lead to promising new developments for digital resources to be used on other populations. None of the included studies assessed the cost-effectiveness of Web-based interventions, which is likely to be an important consideration for policymakers. All the efficacious interventions in this review contained an element of human interaction, either with a real person by videoconferencing or a simulated person in a virtual environment or serious game. The best improvement in outcomes, therefore, may be achieved through a combination of Web-based interventions and human support. As technology evolves rapidly, future Web-based interventions will be more dynamic, perhaps including real-time clinician or therapist input and integrated synchronous crisis support. A promising new development is the use of virtual reality, which has had positive results on children with ADHD [52], adults with anxiety disorders [53], and a range of other mental health problems [54]. Developers could utilize virtual reality to its full effect and enable a simulated, life-like human therapist to support CYP with NDDs and common comorbidities, thus cutting waiting lists while improving outcomes.

\section{Implications for Research}

Future studies of Web-based interventions for CYP with NDDs must have larger sample sizes to generate a reasonable degree of statistical power and allow for an increase in generalizability. They must also consider including long-term follow-up assessments to evaluate whether effects are maintained over a prolonged period. A cost-effectiveness evaluation would also be appropriate and much needed in future research. Furthermore, qualitative feedback in the form of a process evaluation would be useful in addressing the intervention's mechanisms of impact and usability.

Our review found multiple methodological issues with the included trials. Sources of high risk of bias in the RCTs included failure to blind participants and personnel to the Web-based intervention and inadequate reporting of allocation concealment. Failing to blind participants, which can be difficult in Web-based intervention studies, can lead to the digital placebo effect [55]. One possible way of mediating this effect in future studies is to create a sham or static Web-based program for control groups, therefore, reducing the risk of the digital placebo effect. As mentioned, individualized interventions are often the most effective; however, RCT designs are inadequate in assessing the individualized dimension of interventions, therefore future studies should focus on conducting single case experimental designs to measure this [56,57].

\section{Conclusions}

Technological advances and mobile device popularity have huge potential to improve outcomes in CYP with NDDs and comorbid psychological problems. Overall, this study suggests that Web-based interventions can be beneficial in improving symptoms in this population; however, because of the small number of RCTs yielded and several methodological limitations in the included studies, mean findings must be considered with caution. There need to be more studies with larger sample sizes assessing the effectiveness of Web-based interventions for CYP. Furthermore, a qualitative evaluation of the intervention is encouraged in future work to provide bespoke Web-based interventions for youth populations. 


\section{Acknowledgments}

The PhD is funded by National Institute for Health Research (NIHR) MindTech MedTech Cooperative and NIHR Nottingham BRC Mental Health \& Technology Theme. The PhD explores the process evaluation of the Online Remote Behavioral Intervention for Tics Trial, which is funded by the NIHR Health Technology Assessment (Ref 16/19/02).

The PhD studentship is funded by the NIHR MindTech MedTech Cooperative from whom EBD, CH, and CG received financial support. This study is funded by the National Institute for Health Research. The views represented are the views of the authors alone and do not necessarily represent the views of the Department of Health in England, NHS, or the National Institute for Health Research.

CLH acknowledges receiving financial support from NIHR Collaborations for Leadership in Applied Health Research and Care East Midlands.

\section{Authors' Contributions}

KK conducted the literature searches and extracted, tabulated, and interpreted data, contributed to the conception and design of the review, and wrote the manuscript. CLH and EBD aided in the protocol development, performed the second review of the papers, and critically reviewed and revised the manuscript. CG contributed to the conception and design of the review, critically reviewed, and revised the manuscript. $\mathrm{CH}$ approved the final version of the manuscript.

\section{Conflicts of Interest}

None declared.

\section{Multimedia Appendix 1}

Full search strategy.

[PDF File (Adobe PDF File), 135 KB-Multimedia Appendix 1]

\section{Multimedia Appendix 2}

Further information.

[PDF File (Adobe PDF File), 59 KB-Multimedia Appendix 2]

\section{References}

1. Barak A. Psychological applications on the internet: a discipline on the threshold of a new millennium. Appl Prev Psychol 1999 Sep;8(4):231-245. [doi: 10.1016/S0962-1849(05)80038-1]

2. Ahn S, Hwang S. Cognitive rehabilitation with neurodevelopmental disorder: a systematic review. NeuroRehabilitation 2017;41(4):707-719. [doi: 10.3233/NRE-172146] [Medline: 28946583]

3. American Psychiatric Association. Diagnostic and Statistical Manual of Mental Disorders. Fifth Edition. Washington, DC: American Psychiatric Association Publishing; 2013.

4. King BH. Psychiatric comorbidities in neurodevelopmental disorders. Curr Opin Neurol 2016 Apr;29(2):113-117. [doi: 10.1097/WCO.0000000000000299] [Medline: 26840045]

5. Cleaton MA, Kirby A. Why do we find it so hard to calculate the burden of neurodevelopmental disorders. J Child Dev Disord 2018 Mar;4(3):330-338. [doi: 10.4172/2472-1786.100073]

6. Grandjean P, Landrigan PJ. Developmental neurotoxicity of industrial chemicals. Lancet 2006 Dec 16;368(9553):2167-2178. [doi: 10.1016/S0140-6736(06)69665-7] [Medline: 17174709 ]

7. Rutter M. Incidence of autism spectrum disorders: changes over time and their meaning. Acta Paediatr 2005 Jan;94(1):2-15. [doi: 10.1111/j.1651-2227.2005.tb01779.x] [Medline: 15858952$]$

8. McCarthy S, Wilton L, Murray ML, Hodgkins P, Asherson P, Wong IC. The epidemiology of pharmacologically treated attention deficit hyperactivity disorder (ADHD) in children, adolescents and adults in UK primary care. BMC Pediatr 2012 Jun 19;12:78 [FREE Full text] [doi: 10.1186/1471-2431-12-78] [Medline: 22712630]

9. Homberg JR, Kyzar EJ, Scattoni ML, Norton WH, Pittman J, Gaikwad S, et al. Genetic and environmental modulation of neurodevelopmental disorders: translational insights from labs to beds. Brain Res Bull 2016 Jul;125:79-91. [doi:

10.1016/j.brainresbull.2016.04.015] [Medline: 27113433]

10. Whittington C, Pennant M, Kendall T, Glazebrook C, Trayner P, Groom M, et al. Practitioner review: treatments for Tourette syndrome in children and young people - a systematic review. J Child Psychol Psychiatry 2016 Sep;57(9):988-1004. [doi: 10.1111/jcpp.12556] [Medline: 27132945]

11. Anderson M, Jiang J. Pew Research Center. 2018. Teens, Social Media \& Technology 2018 URL: http://www.pewinternet.org/ 2018/05/31/teens-social-media-technology-2018/ [accessed 2019-01-10] [WebCite Cache ID 75K43Vi9Q] 
12. Dovis S, van der Oord S, Wiers RW, Prins PJM. Improving executive functioning in children with ADHD: training multiple executive functions within the context of a computer game. a randomized double-blind placebo controlled trial. PLoS One 2015;10(4):e0121651 [FREE Full text] [doi: 10.1371/journal.pone.0121651] [Medline: 25844638]

13. Spence S, Donovan C, March S, Gamble A, Anderson R, Prosser S, et al. A randomized controlled trial of online versus clinic-based CBT for adolescent anxiety. J Consult Clin Psychol 2011 Oct;79(5):629-642. [doi: 10.1037/a0024512] [Medline: 21744945]

14. Whittaker R, Merry S, Stasiak K, McDowell H, Doherty I, Shepherd M, et al. MEMO--a mobile phone depression prevention intervention for adolescents: development process and postprogram findings on acceptability from a randomized controlled trial. J Med Internet Res 2012 Jan 24;14(1):e13 [FREE Full text] [doi: 10.2196/jmir.1857] [Medline: 22278284]

15. Lenhard F, Andersson E, Mataix-Cols D, Rück C, Vigerland S, Högström J, et al. Therapist-guided, internet-delivered cognitive-behavioral therapy for adolescents with obsessive-compulsive disorder: a randomized controlled trial. J Am Acad Child Adolesc Psychiatry 2017 Jan;56(1):10-9.e2 [FREE Full text] [doi: 10.1016/j.jaac.2016.09.515] [Medline: 27993223]

16. Baumeister H, Reichler L, Munzinger M, Lin J. The impact of guidance on internet-based mental health interventions a systematic review. Internet Interv 2014 Oct;1(4):205-215. [doi: 10.1016/j.invent.2014.08.003]

17. Rogers MA, Lemmen K, Kramer R, Mann J, Chopra V. Internet-delivered health interventions that work: systematic review of meta-analyses and evaluation of website availability. J Med Internet Res 2017 Mar 24;19(3):e90 [FREE Full text] [doi: 10.2196/jmir.7111] [Medline: 28341617]

18. Bishop DV. Which neurodevelopmental disorders get researched and why? PLoS One 2010 Nov 30;5(11):e15112 [REE Full text] [doi: 10.1371/journal.pone.0015112] [Medline: 21152085]

19. Moher D, Liberati A, Tetzlaff J, Altman DG, PRISMA Group. Preferred reporting items for systematic reviews and meta-analyses: the PRISMA statement. PLoS Med 2009 Jul 21;6(7):e1000097 [FREE Full text] [doi: 10.1371/journal.pmed.1000097] [Medline: 19621072]

20. Munn Z. Software to support the systematic review process: the Joanna Briggs Institute System for the Unified Management, Assessment and Review of Information (JBI-SUMARI). JBI Database System Rev Implement Rep 2016 Oct;14(10):1. [doi: 10.11124/JBISRIR-2016-002421] [Medline: 27846109]

21. Higgins JP, Thompson SG. Quantifying heterogeneity in a meta-analysis. Stat Med 2002 Jun 15;21(11):1539-1558. [doi: 10.1002/sim.1186] [Medline: $\underline{12111919]}$

22. Conaughton RJ, Donovan CL, March S. Efficacy of an internet-based CBT program for children with comorbid high functioning autism spectrum disorder and anxiety: a randomised controlled trial. J Affect Disord 2017 Aug 15;218:260-268. [doi: 10.1016/j.jad.2017.04.032] [Medline: 28477505]

23. Esposito M, Sloan J, Tancredi A, Gerardi G, Postiglione P, Fotia F, et al. Using tablet applications for children with autism to increase their cognitive and social skills. J Spec Educ Technol 2017 Jul 18;32(4):199-209. [doi: 10.1177/0162643417719751]

24. Fletcher-Watson S, Petrou A, Scott-Barrett J, Dicks P, Graham C, O'Hare A, et al. A trial of an iPad ${ }^{\mathrm{TM}}$ intervention targeting social communication skills in children with autism. Autism 2016 Oct;20(7):771-782 [FREE Full text] [doi: 10.1177/1362361315605624] [Medline: 26503990]

25. Fridenson-Hayo S, Berggren S, Lassalle A, Tal S, Pigat D, Meir-Goren N, et al. 'Emotiplay': a serious game for learning about emotions in children with autism: results of a cross-cultural evaluation. Eur Child Adolesc Psychiatry 2017 Aug;26(8):979-992. [doi: 10.1007/s00787-017-0968-0] [Medline: 28275895]

26. Whitehouse AJ, Granich J, Alvares G, Busacca M, Cooper MN, Dass A, et al. A randomised controlled trial of an iPad-based application to complement early behavioural intervention in autism spectrum disorder. J Child Psychol Psychiatry 2017 Sep;58(9):1042-1052. [doi: 10.1111/jcpp.12752] [Medline: 28543302]

27. Himle MB, Freitag M, Walther M, Franklin SA, Ely L, Woods DW. A randomized pilot trial comparing videoconference versus face-to-face delivery of behavior therapy for childhood tic disorders. Behav Res Ther 2012 Sep;50(9):565-570. [doi: 10.1016/j.brat.2012.05.009] [Medline: 22743661]

28. Ricketts EJ, Goetz AR, Capriotti MR, Bauer CC, Brei NG, Himle MB, et al. A randomized waitlist-controlled pilot trial of voice over internet protocol-delivered behavior therapy for youth with chronic tic disorders. J Telemed Telecare 2016 Apr;22(3):153-162 [FREE Full text] [doi: 10.1177/1357633X15593192] [Medline: 26169350]

29. Bul KC, Kato PM, van der Oord S, Danckaerts M, Vreeke LJ, Willems A, et al. Behavioral outcome effects of serious gaming as an adjunct to treatment for children with attention-deficit/hyperactivity disorder: a randomized controlled trial. J Med Internet Res 2016 Feb 16;18(2):e26 [FREE Full text] [doi: 10.2196/jmir.5173] [Medline: 26883052]

30. Coutinho F, Bosisio M, Brown E, Rishikof S, Skaf E, Zhang X, et al. Effectiveness of iPad apps on visual-motor skills among children with special needs between 4y0m-7y11m. Disabil Rehabil Assist Technol 2017 May;12(4):402-410. [doi: 10.1080/17483107.2016.1185648] [Medline: 27377131]

31. de Castro MV, Bissaco MA, Panccioni BM, Rodrigues SC, Domingues AM. Effect of a virtual environment on the development of mathematical skills in children with dyscalculia. PLoS One 2014;9(7):e103354 [FREE Full text] [doi: 10.1371/journal.pone.0103354] [Medline: 25068511]

32. Johansson R, Andersson G. Internet-based psychological treatments for depression. Expert Rev Neurother 2012 Jul;12(7):861-9; quiz 870. [doi: 10.1586/ern.12.63] [Medline: 22853793] 
33. Richards D, Richardson T. Computer-based psychological treatments for depression: a systematic review and meta-analysis. Clin Psychol Rev 2012 Jun;32(4):329-342. [doi: 10.1016/j.cpr.2012.02.004] [Medline: 22466510]

34. Thirlwall K, Cooper P, Creswell C. Guided parent-delivered cognitive behavioral therapy for childhood anxiety: predictors of treatment response. J Anxiety Disord 2017 Jan;45:43-48 [FREE Full text] [doi: 10.1016/j.janxdis.2016.11.003] [Medline: 27930939]

35. Byambasuren O, Sanders S, Beller E, Glasziou P. Prescribable mHealth apps identified from an overview of systematic reviews. NPJ Digit Med 2018;1:12 [FREE Full text] [doi: 10.1038/s41746-018-0021-9] [Medline: 31304297]

36. Payne HE, Lister C, West JH, Bernhardt JM. Behavioral functionality of mobile apps in health interventions: a systematic review of the literature. JMIR Mhealth Uhealth 2015 Feb 26;3(1):e20 [FREE Full text] [doi: 10.2196/mhealth.3335] [Medline: 25803705]

37. Yoo JH. The meaning of information technology (IT) mobile devices to me, the infectious disease physician. Infect Chemother 2013 Jun;45(2):244-251 [FREE Full text] [doi: 10.3947/ic.2013.45.2.244] [Medline: 24265976]

38. Torous J, Andersson G, Bertagnoli A, Christensen H, Cuijpers P, Firth J, et al. Towards a consensus around standards for smartphone apps and digital mental health. World Psychiatry 2019 Feb;18(1):97-98 [FREE Full text] [doi: 10.1002/wps.20592] [Medline: 30600619]

39. Smith A. Mashable. 2012. More Smartphone Users Turning to Mobile for Health Info URL: http://mashable.com/2012/11/ 08/mobile-health-adoption/ [accessed 2019-01-10] [WebCite Cache ID 75QMITzRc]

40. Grynszpan O, Martin JC, Nadel J. Multimedia interfaces for users with high functioning autism: an empirical investigation. Int J Hum-Comput Stud 2008 Aug;66(8):628-639. [doi: 10.1016/j.ijhcs.2008.04.001]

41. Aresti-Bartolome N, Garcia-Zapirain B. Technologies as support tools for persons with autistic spectrum disorder: a systematic review. Int J Environ Res Public Health 2014 Aug 4;11(8):7767-7802 [FREE Full text] [doi: 10.3390/ijerph110807767] [Medline: 25093654]

42. Ploog BO, Scharf A, Nelson D, Brooks PJ. Use of computer-assisted technologies (CAT) to enhance social, communicative, and language development in children with autism spectrum disorders. J Autism Dev Disord 2013 Feb;43(2):301-322. [doi: 10.1007/s10803-012-1571-3] [Medline: 22706582]

43. Bölte S, Golan O, Goodwin MS, Zwaigenbaum L. What can innovative technologies do for autism spectrum disorders? Autism 2010 May;14(3):155-159. [doi: 10.1177/1362361310365028] [Medline: 20603897]

44. Ramdoss S, Lang R, Mulloy A, Franco J, O'Reilly M, Didden R, et al. Use of computer-based interventions to teach communication skills to children with autism spectrum disorders: a systematic review. J Behav Educ 2010 Nov 4;20(1):55-76. [doi: $10.1007 / \mathrm{s} 10864-010-9112-7]$

45. Duggan C, Parry G, McMurran M, Davidson K, Dennis J. The recording of adverse events from psychological treatments in clinical trials: evidence from a review of NIHR-funded trials. Trials 2014 Aug 27;15:335 [FREE Full text] [doi: 10.1186/1745-6215-15-335] [Medline: 25158932]

46. Grist R, Cavanagh K. Computerised cognitive behavioural therapy for common mental health disorders, what works, for whom under what circumstances? A systematic review and meta-analysis. J Contemp Psychother 2013 Sep 4;43(4):243-251. [doi: $10.1007 / \mathrm{s} 10879-013-9243-\mathrm{y}]$

47. Higgins JP, Green S, editors. Cochrane Handbook for Systematic Reviews of Interventions. Chichester (UK): John Wiley \& Sons; 2011.

48. Baumeister H, Hutter N, Bengel J. Psychological and pharmacological interventions for depression in patients with diabetes mellitus and depression. Cochrane Database Syst Rev 2012 Dec 12;12:CD008381. [doi: 10.1002/14651858.CD008381.pub2] [Medline: 23235661]

49. Gulliver A, Griffiths KM, Christensen H, Brewer JL. A systematic review of help-seeking interventions for depression, anxiety and general psychological distress. BMC Psychiatry 2012 Jul 16;12:81 [FREE Full text] [doi: 10.1186/1471-244X-12-81] [Medline: 22799879]

50. Nugent BM, O'Donnell CM, Epperson CN, Bale TL. Placental H3K27me3 establishes female resilience to prenatal insults. Nat Commun 2018 Jul 2;9(1):2555 [FREE Full text] [doi: 10.1038/s41467-018-04992-1] [Medline: 29967448]

51. NHS England. 2016. Children and Young People's Mental Health Local Transformation Plans - A Summary of Key Themes URL: https://www.england.nhs.uk/mentalhealth/wp-content/uploads/sites/29/2016/08/cyp-mh-ltp.pdf [accessed 2019-01-10] [WebCite Cache ID 75FDHjq8G]

52. Bashiri A, Ghazisaeedi M, Shahmoradi L. The opportunities of virtual reality in the rehabilitation of children with attention deficit hyperactivity disorder: a literature review. Korean J Pediatr 2017 Nov;60(11):337-343 [FREE Full text] [doi: 10.3345/kjp.2017.60.11.337] [Medline: 29234356]

53. Reger GM, Holloway KM, Candy C, Rothbaum BO, Difede J, Rizzo AA, et al. Effectiveness of virtual reality exposure therapy for active duty soldiers in a military mental health clinic. J Trauma Stress 2011 Feb;24(1):93-96. [doi: 10.1002/jts.20574] [Medline: 21294166]

54. Valmaggia LR, Latif L, Kempton MJ, Rus-Calafell M. Virtual reality in the psychological treatment for mental health problems: an systematic review of recent evidence. Psychiatry Res 2016 Feb 28;236:189-195. [doi:

10.1016/j.psychres.2016.01.015] [Medline: 26795129] 
55. Torous J, Firth J. The digital placebo effect: mobile mental health meets clinical psychiatry. Lancet Psychiatry 2016 Feb;3(2):100-102. [doi: 10.1016/S2215-0366(15)00565-9] [Medline: 26851322]

56. Carr ME, Anderson A, Moore DW, Evans WH. How should we determine treatment effectiveness with single-case design research for participants with autism spectrum disorder? Rev J Autism Dev Disord 2014 Jul 19;2(1):8-18. [doi: 10.1007/s40489-014-0030-9]

57. Carr M, Moore D, Anderson A. Self-management interventions on students with autism. Except Child 2014 Sep 16;81(1):28-44 [FREE Full text] [doi: 10.1177/0014402914532235]

\title{
Abbreviations
}

ADHD: Attention deficit hyperactivity disorder

ASD: Autism Spectrum Disorder

CBIT: Comprehensive Behavioural Intervention for Tics

CBT: cognitive behavioral therapy

CG: control group

CTD: Chronic Tic Disorder

CYP: children and young people

DSM: Diagnostic and Statistical Manual of Mental Disorder

ER: emotion recognition

F2F: face-to-face

HFASD: high-functioning autism spectrum disorder

ITT: intention-to-treat

JBI: Joanna Briggs Institute

LD: learning disorder

MEDLINE: Medical Literature Analysis and Retrieval System Online

NDD: neurodevelopmental disorder

NHS: National Health Service

NIHR: National Institute for Health Research

OT: occupational therapy

RCT: randomized controlled trial

SMD: standardized mean difference

SUMARI: System for the Unified Management, Assessment and Review of Information

TAU: treatment as usual

TD: tic disorder

TOBY: Therapy Outcomes By You

VMI: visual-motor integration

WLC: waitlist control

\author{
Edited by G Eysenbach; submitted 11.03.19; peer-reviewed by A Anderson, C Liang, A Wickersham; comments to author 25.04.19; \\ revised version received 12.06.19; accepted 28.07.19; published 01.11.19 \\ Please cite as: \\ Khan K, Hall CL, Davies EB, Hollis C, Glazebrook C \\ The Effectiveness of Web-Based Interventions Delivered to Children and Young People With Neurodevelopmental Disorders: Systematic \\ Review and Meta-Analysis \\ J Med Internet Res 2019;21(11):e13478 \\ URL: https://www.jmir.org/2019/11/e13478 \\ doi: $10.2196 / 13478$ \\ PMID: 31682573
}

(CKareem Khan, Charlotte L Hall, E Bethan Davies, Chris Hollis, Cris Glazebrook. Originally published in the Journal of Medical Internet Research (http://www.jmir.org), 01.11.2019. This is an open-access article distributed under the terms of the Creative Commons Attribution License (https://creativecommons.org/licenses/by/4.0/), which permits unrestricted use, distribution, and reproduction in any medium, provided the original work, first published in the Journal of Medical Internet Research, is properly cited. The complete bibliographic information, a link to the original publication on http://www.jmir.org/, as well as this copyright and license information must be included. 